\title{
The cultural landscape as a cross-cutting resource for tourism products in low-density rural territories: diagnosis and guidelines for Alto Minho (NW Portugal)
}

\author{
A. Pereira \\ Faculty of Arts of the University of Coimbra, \\ Centre of Studies on Geography and Spatial Planning (CEGOT), \\ Portugal
}

\begin{abstract}
In Northern Portugal rural tourism is one of the most successful tourism sectors: the number of establishments rose by $30 \%$, and the accommodation capacity registered a growth of $48 \%$ between 2002 and 2011. The evolution trends of rural and nature based tourism in Northern Portugal open new perspectives to the development of an integrative approach to tourism offer, where cultural landscape may be valued as a cross-cutting resource, as well as to the reinforcement of secondary demand.

Alto Minho (NW Portugal) is a predominantly low-density rural territory, with a rich cultural landscape shaped by agro-pastoral communities since the Neolithic. The concentrated diversity of potential tourism attractions and the combination of natural and cultural heritage stands as main distinguishing factors of Alto Minho as a tourism destination.

This research work aims to show how the acknowledgment of cultural landscape unities at a regional scale is as a crucial instrument for the conception of interpretative itineraries, joining different kind of tourism resources, from natural to cultural heritage.

Despite the short-term growth potential of rural and nature based tourism, its expansion may benefit from the development of a more integrated offer, widening the motivation spectrum. Heritage and cultural landscape touring may play a crucial role in the articulation of different tourism resources. This strategy proves to be the most advantageous one in the case of low-density rural areas. Keywords: cultural landscape, nature based tourism, rural tourism, touring.
\end{abstract}




\section{Nature based tourism: trends and strategies}

The Portuguese National Strategic Plan for Tourism (PENT [1]) establishes, for the period 2006-2015, that the products with potential to catalyse short-term growth in the region of Porto and North of Portugal, where Alto Minho is inserted, are City Break, Touring and Nature Tourism.

Nature based tourism is considered to be one of the fastest growing markets within the sector worldwide, with a growth rate between $10 \%$ and $12 \%$ per year (Tangeland and Aas [2]; Fredman and Tyrväinen [3]). Nevertheless the current economic frame prevented the confirmation of this numbers; the main evolution trend still is a meaningful indicator.

In Portugal, nature based tourism is expected an annual growth of $9 \%$ in a 10 year scenario, a value even higher than those estimated at a European level (AEP [4]). However, 96\% of the demand corresponds to inbound tourism (THR [5]). Most of the outbound tourists are visitors who have travelled to Portugal for other reasons and that, once in the country, get interested in some form of nature tourism. This puts in evidence the weak position of Portugal as a destination for nature tourism trips in the international market (as main reason) and the importance of the concept of secondary demand.

Thereby, despite the short-term growth potential of nature tourism in North Portugal, its expansion may benefit from the development of a more integrated offer, widening the motivation spectrum through the combination of nature tourism, in a strict sense, with other branches of the tourism sector, taking advantage of the diversity of resources in the territory. Given the proximity and the intrinsic relation between the majority of natural environments, namely the protected areas, and the rural spaces in Alto Minho, Heritage and Cultural Landscape Touring may play a crucial role in the articulation of different tourism resources.

The gaps in the regional organization of nature based tourism induced the Comunidade Intermunicipal do Alto Minho (Upper Minho Inter-Municipal Community) to lead the development of a number of projects, coordinating the intents and efforts of the different municipalities.

The strategy for the sustainable and profitable management of the environmental resources of Alto Minho adopted by the Inter-Municipal Community establishes two main guidelines: the qualification of the greenways and the valorisation of the areas of environmental excellence. Aiming to create a backbone of the walking routes in Alto Minho, approaching the valley and the hilly areas, two new great routes are being implemented: the littoral and the mountain routes. The network of greenways in Alto Minho is due to be extended to $164 \mathrm{~km}$ long.

The global outlook of this strategy highlights the strong focus on pedestrianism as a way to promote leisure and tourism in natural areas. Thereby, aiming to achieve a deeper approach to this strategy, some important issues must be addressed:

- Which is the market of this type of nature based tourism in northern Portugal? 
- What criteria are being observed in the restructuring of Alto Minho greenways, namely the projected great routes?

- Is natural and cultural heritage being properly considered in an integrative approach to tourism resources?

- May Alto Minho greenways' take advantage from exploring complementarities and synergies with heritage and cultural landscape touring?

The reflection on these questions may contribute to improve the regional nature based tourism strategy, enlarging the growth potential of this sector.

This research addresses the possibilities and advantages of integrating nature tourism with other products with strong synergies, such as rural tourism and touring. The definition, characterization and cartography of cultural landscape unities play a crucial role in the conception of tourism products based in the interpretation of the inter-relation between men and nature, bringing together natural and cultural heritage. Indeed, the acknowledgment of cultural landscape unities at a regional scale is as a crucial tool for the conception of interpretative itineraries.

An itinerary of cultural and landscape touring, linking the Arga ridge and the valley of Lima River will be developed, putting into practice the proposed strategy.

\section{Upper Minho nature based tourism resources}

The north-western region of Portugal, Alto Minho develops between the Lima River, its southern limit, and the Minho River that defines the boundary with North Spain.

More than inventorying the values that may support the development of nature based tourism products, it is important to stress how they can contribute to differentiate Alto Minho as a tourism destination. The concentrated diversity of potential tourist attractions and the combination of natural and cultural heritage elements, expressed in an evolutionary cultural landscape, stands as the main distinguishing factors.

Therefore, the nature based tourism resources of Alto Minho can only be understood in the frame of the interpretation of its cultural landscape, including the explanation of its physical and historical conditioning factors.

\subsection{A complex and diversified landscape mosaic}

The organization of the landscape of Alto Minho is defined by four main vectors: the contrast between lowlands and mountainous areas, more specifically between the alluvial plains and the surrounding hills and ridges, an agro-pastoral and forestry matrix built over several centuries, a scattered settlement pattern, where only stands some medium-scale centres and, at least, the strong fragmentation of rural property.

The complex organization of this territory results from the overlap of land occupation models and strategies from different historical periods. Indeed, the 
archaeological research conducted since the second half of the last century revealed that the regional landscape organization clearly shows the most important marks of the human presence. In this way, the archaeological remains offer meaningful evidences for the interpretation of landscape evolution.

The integrated study of natural and cultural heritage contributes to increase the knowledge about the options and strategies adopted in different periods in what concerns to the location of population centres, land use patterns, exploitation of natural resources, mobility networks or landownership models.

The landscape mosaic of Alto Minho highlights the crucial influence of the underling relief structure. The antagonism between the riverside and the mountain areas has a remarkable impact on the settlement models and on the distribution of the productive activities. In a closer look, the importance of tectonic valleys, granitic alveolus and natural terraces stands out. Similarly, the lithology strongly influences the landscape mosaic, conditioning the pedologic properties and the soil suitability. Its influence is particularly evident in the contact areas between granites and shales and in the alluvial plain of river Lima.

The terrain of Alto Minho is compared to mosaic of blocs (Ferreira [6]), defined by the intersection of tectonic lineations of the hercynian (NW-SE/NNW-SSE) and alpine (NE-SW/ENE-WSW) orogenies. The open valleys, conditioned by the betic direction, are delimited by a sequence of horsts, which elevation decreases from east to west. These mountain ridges are mainly constituted by granitic rocks, deeply cut by fracture alignments of late-hercynian (NNW-SSE) or alpine orogenies, whose directions determine the major rivers in the region and their main tributaries (Rebelo [7]). Despite the intense fracturing, it is still possible to identify several well preserved flattened levels in the mountain systems of NW Portugal - such as those of Gerês, at 1400 meters of height, Peneda about 1100-1200 meters, Cabreira around 900-1000 meters and Arga ridge at a 800 meters (Feio [8]). These levels correspond to conserved remains of extensive erosion surfaces (Martin-Serrano [9]). The tectonic action is patent in the orientation of the hydrographical network and in the enlargement of the main valleys. Consequently, the pre-ordovician schist-greywacke complex, the Ordovician quartzites and different types of hercynian granites stands out in the geological frame.

Three specific features of the regional morphology determine, at a great extent, the location of the rural settlements, as well as the distribution of the agricultural area: the cross-profile of the main valleys, the great number and remarkable dimension of granitic alveolus and the importance of natural terraces for the development of hilly villages.

Now we will present a synthesis of the main historical processes that influenced the evolution of the territory organization in Alto Minho. The Castro culture played a key role in shaping the landscape of the mountainous areas. During the early centuries of the first millennium B.C., Alto Minho landscape have been deeply transformed by the new agropastoral and forestry systems structured around the settlements fixed in middle slope. More than 31 hill forts were identified in the watershed of river Lima (Almeida [10]): fortifications that defined the concentration of the agro-pastoral communities on strategically 
defensive points of the hills and mountains. The demand for arable land and pastures in the area of influence of each hill fort triggered the deforestation and prevented the growth of shrubs in the highlands (Almeida [11]). The present mountain settlement may be regarded as an evolutionary heritage of the Pre-Roman land organization. Hill forts occupation persists under the Roman domain, being often continued until the Middle Ages.

Roman settlements established essentially on valley areas, with gentle slopes and more fertile soils. Romans were responsible by the deforestation the alluvium plains and drainage of marshy areas, modifying land occupation patterns and stimulating the evolution of agroforestry systems. The disperse settlement and strong parcelling that characterises the lowlands of Alto Minho finds its roots on the Roman period, whose land occupation matrix, agrarian organization and property division is rebuild over new power and social hierarchies during the Early Middle Ages. The Roman villaes consisted in agro-cattle proprieties, whose exploration was commonly carried out by slave or employed workmanship. The north-western settlement in the Roman period would lie on a villae network more or less scattered (Sampaio [12]). Summing up, the modern north-western rural landscape was shaped during Proto-History, with the Castro settlement model that occupied the hilly slopes of the major valleys. The subsequent settlement, Roman and Medieval, organized and increased the density of the occupation of the lowland areas (Martins [13]). Notice that the influence of the Castro settlement pattern still remains visible at the present, reflected in a system of isolated places of small dimension.

This summary of landscape evolution, combining natural and historical factors, contributes to the understanding of the present landscape mosaic.

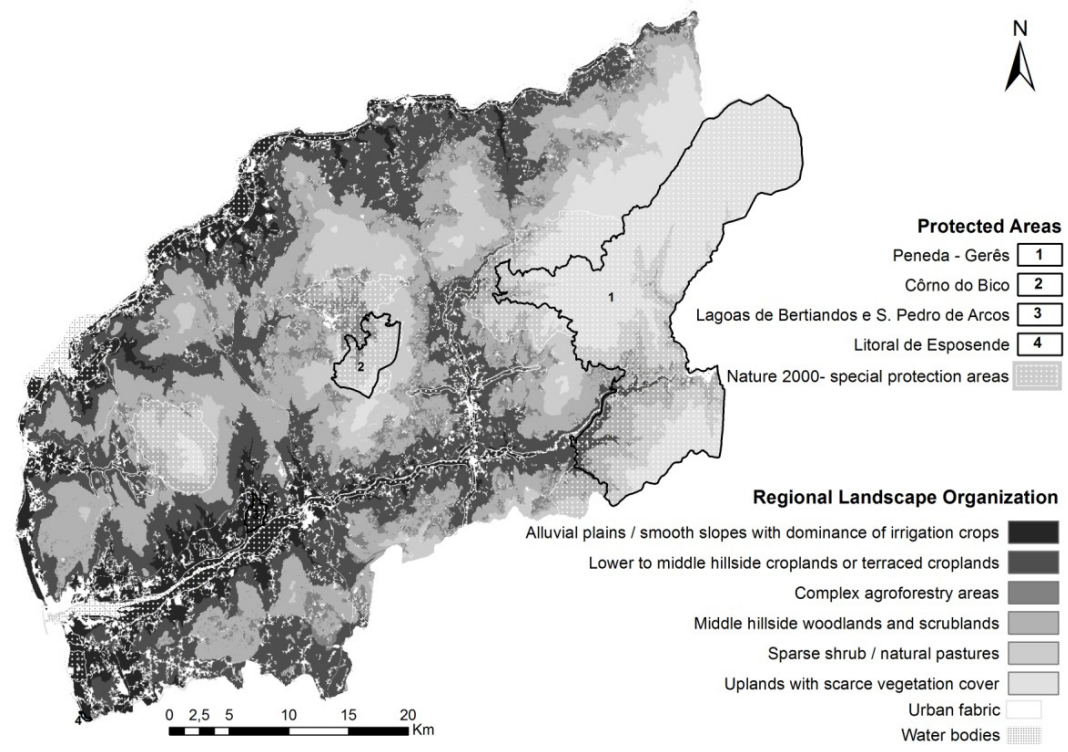

Figure 1: Regional landscape organization. 
The cartography of the main levels of landscape organization in Alto Minho, presented in figure 1, was based in the weighted correlation between elevation, lithology, slope and soil use, following a methodology similar to the one presented in Batista et al. [14]. The resulting map allows us to identify six main levels of landscape organization in Alto Minho, expressing the relation between the soil use and the biophysical support:

1) Alluvial plains / smooth slopes with dominance of irrigation crops,

2) Lower to middle hillside croplands or terraced croplands,

3) Complex agroforestry areas,

4) Middle hillside woodlands and scrublands,

5) Sparse shrub / natural grasslands or pastures,

6) Uplands with scarce vegetation cover.

The conservation areas present in this region, also represented in figure 1, includes the National Park Peneda-Gerês, the Protected Landscape of the Lagoas de Bertiandos e S. Pedro de Arcos and the Protected Landscape of Corno do Bico, as well as the sites of community importance and special protection areas of the rivers Minho and Lima, Litoral Norte and Serra de Arga, integrated in Nature 2000. Notice the strong diversity of habitats; including mountain areas, estuarine corridors and coastal environments that mark this network in Alto Minho. With more than 61200 ha included within the Nature 2000 network and 34300 ha of conservation areas, Alto Minho reinforces its potential for nature based tourism with a rich cultural landscape mosaic.

\section{Taking advantage from cultural landscape as a cross-cutting resource for tourism products}

In the Portuguese network of protected areas (ThinkTur [15]) spontaneous visitation largely overcomes structured visitation: the first represents over $80 \%$ and the second less than $20 \%$. These figures stress the need of finding innovative ways to expand the market of nature based tourism in Alto Minho. Achieving this goal requires a greater balance in the tourism use of the different natural and rural areas and the integration of complementary tourism resources, aiming to stimulate and take advantage of the secondary demand. A practical example of this approach will be presented for the valley of the Lima River.

\subsection{Integrating tourism offer in the valley of the Lima River: from high-quality rural tourism to cultural and landscape touring}

The number of rural tourism establishments in Portugal increased by 33\% between 2002 and 2011 (Turismo de Portugal [16]), while the accommodation capacity, measured in number of bed places, grew $58 \%$. In the same period, the number of nights spent increase over $90 \%$.

In northern region, where rural tourism has a longer tradition, the number of establishment rose by $30 \%$, and the accommodation capacity registered a growth of $48 \%$ between 2002 and 2011 . The number of nights spent increased by $83.62 \%$. In 2011 , this region gathered near $40 \%$ of the total accommodation 
capacity provided by rural tourism in the country and represented about $31 \%$ of the nights spent in this kind of lodgement.

The promising evolution trends of rural tourism in Portugal and the importance of the offer centred in northern region opens new perspectives to the expansion of nature based tourism trough the exploitation of secondary demand. The motivations and expectations of rural tourists and eco-tourists corroborate this point of view. A survey on German tourists (European Commission [17]), one of the most important European outbound markets for nature based tourism, states that the four most important expectations for tourists seeking nature and culture orientated holidays are as follows:

- $\quad$ " $50 \%$ expect small accommodation businesses run by locals;

- $45.6 \%$ want to go hiking by themselves and want to be furnished with good information;

- $\quad 41.2 \%$ expect local cuisine with local ingredients;

- $41.2 \%$ expect strong local hospitality; they want to feel welcome".

This survey highlights how the conciliation of the offer of nature based tourism and rural tourism may fulfil the expectations of this market segment, valuing the combination of locally based hotel businesses, local productions and easy access to autonomous trekking.

An inquiry on the motivations of the guests of rural tourism establishments (Instituto de Estudos Sociais e Económicos [18]) pointed out that the discovery of a region and the contact with nature were the most cited reasons to choose this kind of accommodation.

The valley of the Lima River was the cradle of TURIHAB, a network of characterful rural properties, under the brand name Solares de Portugal, comprising small hotels, individual homes and apartments. This rural tourism network of excellence may be enriched by the integration with the regional offer of nature based tourism, specially by favouring the access to the more than 70 hiking treks spread all over the valley of river Lima, both inside and outside of the conservation areas.

\subsection{Climbing the hill: understanding a cultural landscape}

Aiming to demonstrate how the identification and cartography of cultural landscape unities may be a crucial tool for the conception of interpretative itineraries; a road route was developed in Arga ridge aiming to:

- Conceive an itinerary representative of the cultural landscapes mosaic,

- Stimulate the practice of hiking by rural tourism guests,

- Show how the interrelation between built heritage and cultural landscape may enrich the process of discovering a territory.

The Cultural Itinerary of the Arga Ridge, presented in the figure 2, consists of an open route of $34 \mathrm{~km}$, meant to be done by car, which guides the visitor through a narrative of the man occupation of this territory and of the shaping of its landscape, taking advantage of an integrated analysis of the environmental and built heritage. 


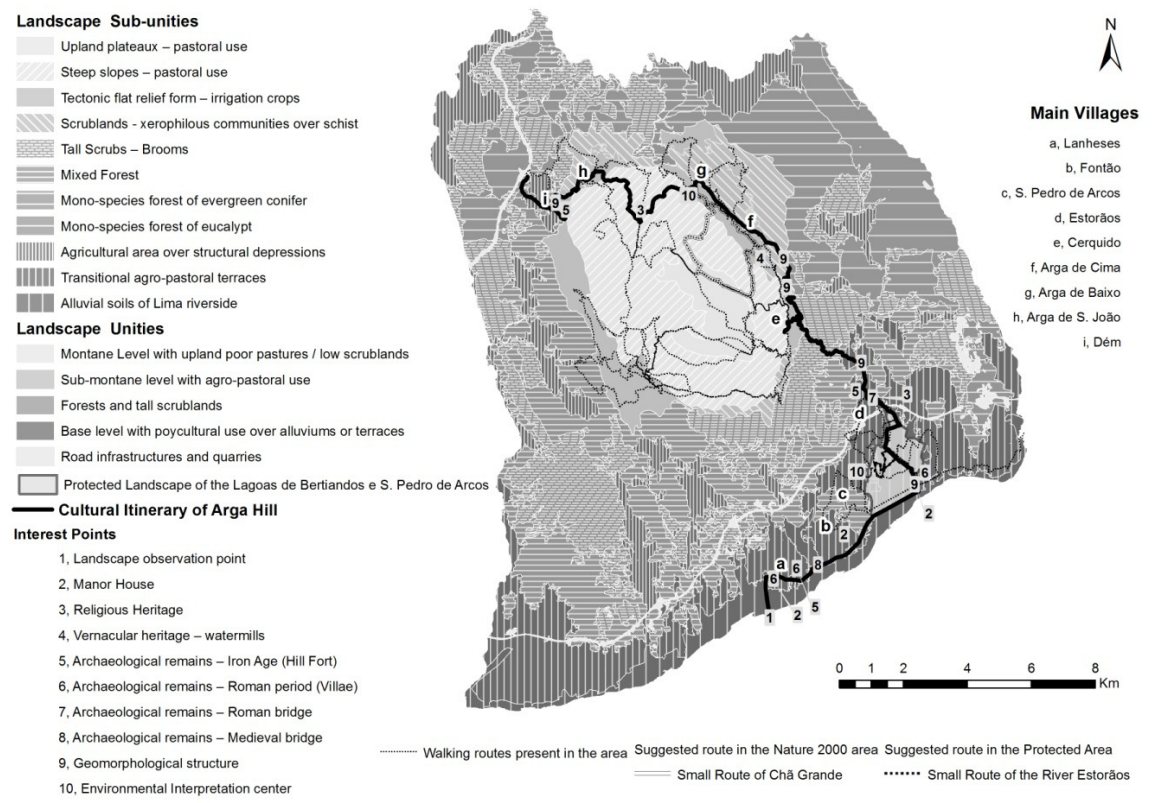

Figure 2: Cultural Itinerary of Arga Ridge exploring the classification of landscape unities.

It begins on the edge of river Lima, facing the so-called Lugar da Passagem: a river crossing site integrated in a pre-Roman route, later consolidated during the imperial occupation and continued to be used during the medieval ages. The antiquity of this route was attested by the discovery of two dugouts dated between the 4 th and 2 nd centuries BC. Then, the itinerary follows a national road, which develops along the fertile plain of the river Lima, a sediment deposition area intensively occupied by irrigated crops. The several archaeological remains that were identified nearby this section of the route prove the occupation of the alluvial plain and of the low hillside sectors by agricultural hill forts, during the High Empire, as well as the implementation of roman villae or even medieval agricultural exploitation unities based on family cells. This starting point provides a clear sight of the contrast between the alluvial plain of river Lima and the south-western slope of Arga ridge in terms of their morphology, vegetation and soil use (figure 3).

The route veers towards a secondary road that goes through the Protected Landscape of the Lagoas de Bertiandos e S. Pedro de Arcos, crossing the valley of Estorãos River and enabling the possibility of hiking in a small route that penetrates into this conservation area - the only wet zone that benefits of a special protection status in northern Portugal - conducting to its Environmental Interpretation Centre. 


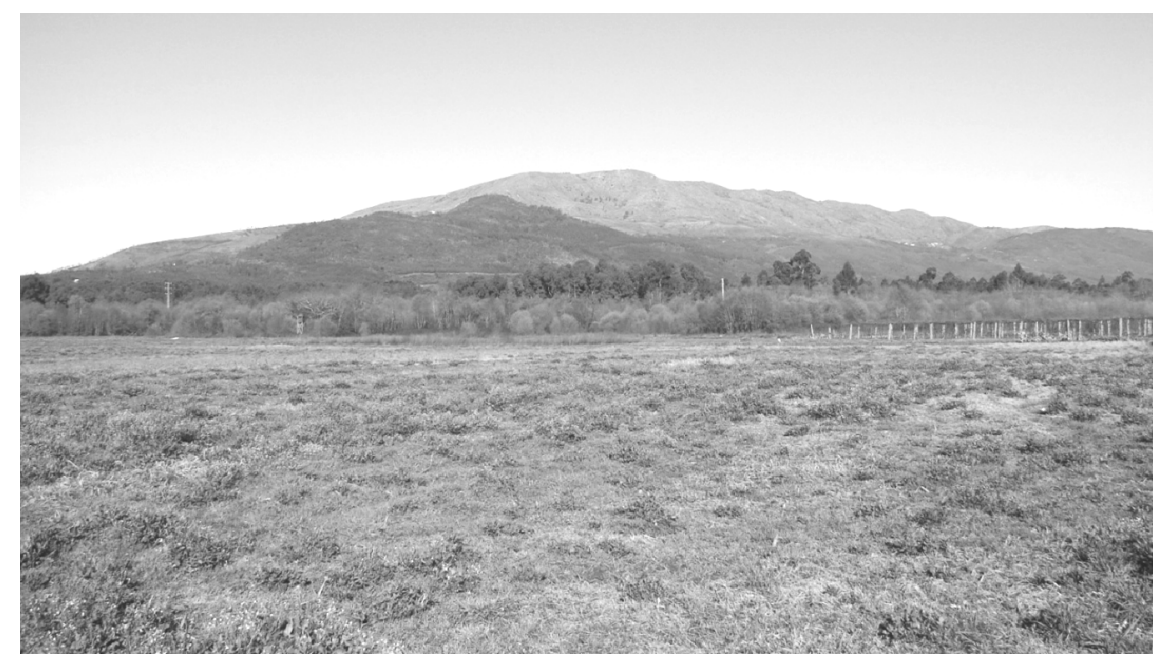

Figure 3: Landscape contrast between the alluvial plain and the Arga Ridge.

Following the road that climbs the southeast slope of the Arga Ridge, towards the small village of Cerquido (figure 4), one may observe a clear fault scarp. This village develops between 400 and 430 meters of height, in a well defined tectonic terrace. With a privileged geostrategic location, Cerquido has a unique visual basin, encompassing the valley of Estorãos River and the middle sector of the alluvial plain of the Lima River.

Climbing to the central granitic massif it is possible to observe the geological contact between the granite of Serra de Arga and black schists of the Unite of Minho. Following along the tectonic flat level we found the three main mountain villages of this route, surrounded by a complex agricultural area constituted by a mix of croplands and natural pastures. It is possible to have access to several small routes that leads us to the hilltop surface, area with a great diversity of granitic landforms.

Starting the way down, we will find an Early Middle Ages monastery that still is an important pilgrimage place: the Monastery of S. João de Arga, dated from the $13^{\text {th }}$ century.

At least, the route meets the tectonic depression of Dem. This graben is marked by the agricultural use of the base of the slopes through archaic terraces. In a dominant elevation nearby the parish church we found the remains of a hill fort known as Castro do Germano, which probably has explored the fertile soils of the neighbour depression. The fertility of the soil of this graben is not due to the geological schist substrate but to sediment accumulation from upstream of slopes. 


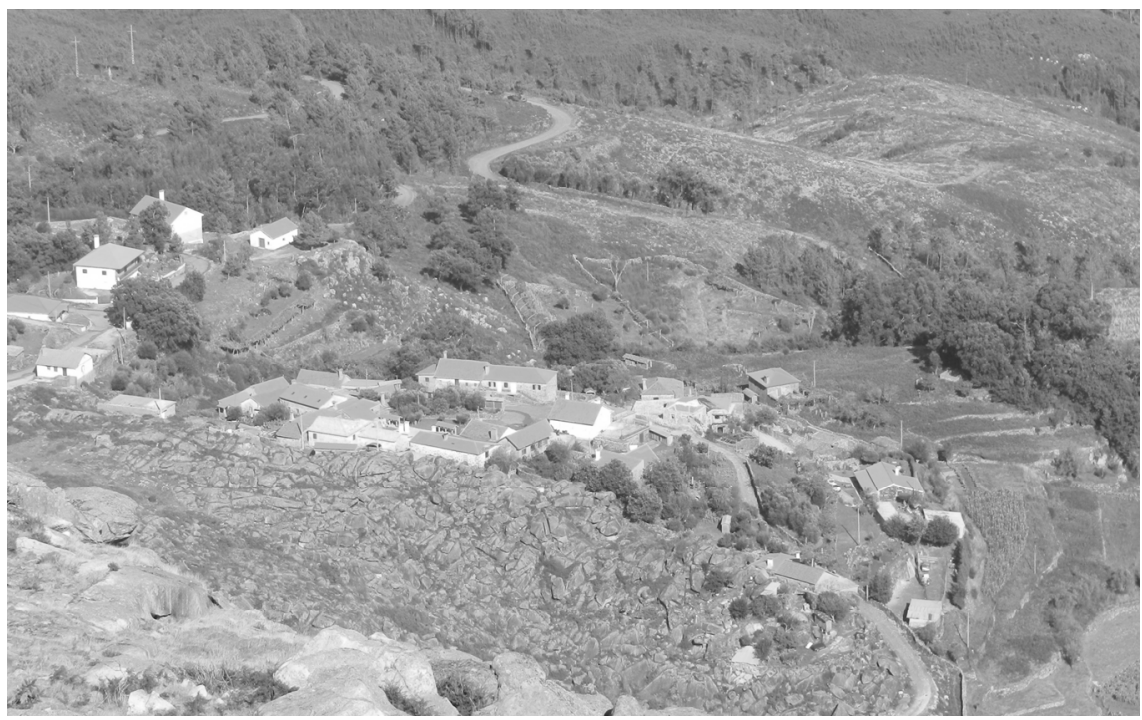

Figure 4: Cerquido: a village and its agro-pastoral area in the Arga Ridge.

\section{Final words: some advice on the promotion of nature based tourism}

The exposed exercise aimed to show how the exploration of the concept of cultural landscape may contribute to a comprehensive interpretation of the territory and to the development of a space-based narrative to guide its discovery by the visitants.

The strategy based on the complementarities between rural tourism, nature tourism and cultural and landscape touring is the most advantageous one in the case of low density rural areas, with an ancient human occupation and high diversity of natural and cultural heritage, such as the region of Alto Minho.

The success of this approach may benefit from the following recommendations:

- Analyse the profile of the tourists that already visit the region, particularly at the segments of rural tourism and landscape and cultural touring;

- Design walking routes considering the demand of soft nature consumers, in order to satisfy the expectations of rural tourism guests;

- Pay special attention to the suitability of mobility solutions and meet the information needs of the target publics;

- Attract and guide potential hiking practitioners by the conception of interpretative road routes linking the existing footpaths;

- Diversify the scenic context of the walking routes, avoiding monotony, and the typology of interest points, offering a holistic overview of local environmental and cultural values; 
- Take more advantage of the tourism infra-structures and services already available in the territory, promoting its use in the scope of integrated tourism products.

\section{References}

[1] Turismo de Portugal, Plano Estratégico Nacional de Turismo (PENT). Ministério da Economia e da Inovação: Lisboa, 2007, Online.

http://www.turismodeportugal.pt

[2] Tangeland, T. \& Aas, Ø., Household composition and the importance of experience attributes of nature based tourism activity products - A Norwegian case study of outdoor recreationists. Tourism Management, 32(4), pp. 822-832, 2011.

http://www.sciencedirect.com/science/article/pii/S0261517710001500

[3] Fredman, P. \& Tyrväinen L., Frontiers in Nature-Based Tourism. Scandinavian Journal of Hospitality and Tourism. 10(3), pp. 187-189, 2010 .

http://www.tandfonline.com/doi/abs/10.1080/15022250.2010.502365

[4] AEP/Gabinete de Estudos. (2008). Turismo de Natureza. Estudo de Mercado. Lisboa: Turismo de Portugal.

http://www.aep.org.pt/publicacoes/estudos-de-mercado-aep

[5] THR - Asesores en Turismo Hotelería y Recreación, S.A. (2006). Turismo de Natureza. 10 produtos estratégicos para o desenvolvimento do turismo em Portugal. Lisboa: Turismo de Portugal, IP.

http://www.turismodeportugal.pt/Portugu\%C3\%AAs/turismodeportugal/p ublicacoes/Documents/Turismo\%20de\%20Natureza\%202006.pdf

[6] Ferreira, A., O Relevo de Portugal. Grandes Unidades Regionais. Associação Portuguesa de Geomorfólogos: Coimbra, 2004.

[7] Rebelo, F., Relevo de Portugal - uma introdução, Inforgeo, 4, pp. 17-35, 1992.

[8] Feio, M., Reflexões sobre o relevo do Minho. Notas Geomorfológicas, 1, pp. 5-33, 1951.

[9] Martin-Serrano, A. El relieve de la región occidental zamorana. La evolutión geomorfológica de un borde del macizo Hespérico., Instituto de Estudios Zamoranos 'Florian de Ocampo': Zamora, 1988.

[10] Almeida, C., Povoamento Romano do Litoral Minhoto entre o Cávado e o Lima. Ph.D. thesis., Universidade do Porto: Porto, 1996.

[11] Almeida, C., Da pré-história à Romanização (vol. I), Sitios que fazem história. Arqueologia do concelho de Viana do Castelo, Câmara Municipal de Viana do Castelo: Viana do Castelo, 2008.

[12] Sampaio, A. Estudos históricos e económicos: As villas do Norte de Portugal, Vega: Lisboa, 1979.

[13] Martins, M., As vilas do norte de Portugal. Revista de Guimarães, 102, pp. 387-409, 1992.

[14] Batista, T. et al., Unidades Locais de Paisagem: ensaio aplicado à área Alentejo-Extremadura no âmbito OTALEX II /Unidades Locales de 
Paisaje: ensayo aplicado al área Alentejo-Extremadura en el âmbito de OTALEX II., Batista, T, et al. (coord.), OTALEX II - Resultado do Projecto - Resultado del Proyeto. 81-96 s.1.: Ed. CIMAC e Dir. Gen. Urb. y Orden. Territ. 2011.

[15] ThinkTur Estudos e Gestão de Empreendimentos Turísticos, Lda., Programa de Visitação e Comunicação na Rede Nacional de Áreas Protegidas. Instituto da Conservação da Natureza: Lisboa, 2006, Online. http://www.icn.pt/portal/portal/cpublica/PVisitacao/visitacao_aps/relatorio 2fase/PVC_RNAP_R2_1.pdf

[16] Turismo de Portugal, Anuário das Estatísticas do Turismo 2011, 2012, Online.

http://www.turismodeportugal.pt/Portugu $\% \mathrm{C} 3 \% \mathrm{AAs} /$ ProTurismo/estat $\% \mathrm{C}$ 3\%ADsticas/an\%C3\%A1lisesestat\%C3\%ADsticas/oturismoem/Pages/OT urismoem.aspx

[17] European Commission. Tourism Unit. Using natural and cultural heritage to develop sustainable tourism in non-traditional tourist destinations (n. ${ }^{\circ}$ 285). Enterprise Directorate General - Tourism Unit: Brussels, 2002. Online.

http://ec.europa.eu/enterprise/sectors/tourism/files/studies/using_natural_c ultural_heritage/market_trends_en.pdf

[18] Instituto de Estudos Sociais e Económicos, Estudo de Caracterização do Turismo no Espaço Rural e do Turismo de Natureza em Portugal. Direcção Geral de Agricultura e Desenvolvimento Rural: Lisboa, 2008, Online. http://www.dueceira.pt/docs/publicacoes/99_estudo\%20TER.pdf 